\title{
Transformative Ecumenical Economic Justice: Implications for the Church's Witness within the Southern African Context
}

\section{Roderick R. Hewitt \\ ORCID iD: https://orcid.org/0000-0003-1226-4671}

\begin{abstract}
This article argues that sections of the religious community are no longer willing to stand aside and wait on government and international economic and financial organisations to decide when to act to bring about transformative economic justice that can benefit the poor of the earth. Through the initiates of ecumenical organisations such as the World Council of Churches (WCC), World Communion of Reformed Churches (WCRC), and The Council for World Mission (CWM). Tentative steps have been taken since 2012 that offer a critique of and solutions to issues in the global financial sector, public finance and debt, and the global economic governance. These religious communities argue that the global financial and economic system are not constructed or committed to principles for an Economy of Life for all earth's inhabitants but a select few. The article further argues that the peoples of the African continent, and especially those within the Southern African context that is dominated by the Christian religion, ought to engage in joint ecumenical action that can urgently address the gross inequality in wealth distribution and major fall-out in social cohesion.
\end{abstract}

Keywords: Economy, Transformative Ecumenism, Economic justice, Colonialism, Neo-liberalism, Empire

\section{Introduction}

The World Council of Churches (WCC), World Communion of Reformed Churches (WCRC), The Lutheran World Federation (LWF), and the Council for World Mission (CWM) are leading ecumenical institutions that have 
engaged in theological enquiry into the global economy, financial architectural structure, and the mission of the Church over the past two decades. They called into question the Christian community's focus in offering fullness of life for all. Their ecumenical critique of the financial sector, public finance and debt, and the global economic governance exposed that they are not constructed on principles for an Economy of Life for all earth's inhabitants, but a select few (WCRC-WCC-CWM Sao Paolo Statement on International Financial Transformation for an Economy of Life). All of these ecumenical organisations have member churches within the Southern African context, and their work has major significance for the wellbeing of peoples in local communities. Fundamental changes in global policies and structures that affect the economy of African nations are urgently needed, and this necessitates joint ecumenical action at national and global levels. This reflection is limited in scope and as the title implies, where emphasis is placed on ecumenical discourses on economic justice, and the implications for Christians within the Southern African context. This article therefore examines ecumenical perspectives on economic justice in conversation with the Church's witness in facilitating the emergence of an 'economy of life'. The article draws upon the two-volume research on globalisation within the African context of Reformed theologians, Allan Boesak and Len Hansen, and their team of scholars (Boesak and Hansen, 2009). Their three-year project emerged out of the Reformed churches within the Southern African context, seeking to respond to the WCRC's Accra Confession that called on churches to 'Covenanting for Justice in the Economy and Earth'. This trans-disciplinary study explored the subject of globalisation from biblical perspectives, theological foundations, confessional traditions, and socio-ethical values (Boesak \& Hansen 2010: ix). The limited scope of this article, therefore, draws on textual sources, rather than engaging in case study methodology, to gather and examine important data.

\section{Blessings and Curses of Globalisation}

Any exploration on the challenges faced by ecumenical organisation in working for economic justice must face up to the reality that the politicoeconomic phenomenon of globalisation and neoliberal capitalism are ideologically driven forces by global financial powers that control global trade. This focus on the interconnectivity between the global economy and financial architectural structure and wealth, poverty, and ecology within the Southern 
African region, constitutes an urgent agenda. Economic globalisation has accompanied imperial colonisation within Africa through European political conquest (Boesak \& Hansen 2009: i; 2010: 1). The two-volume work on globalisation was published after the 2008 global financial crisis and recession that ruined many lives and called into question the underlying assumptions of the policies employed by global financial institutions in managing the global economy and trade. With governments having to bail out many of these institutions, international ecumenical organisations again called for serious rethinking of how the global systems are designed to work, and whose interests they serve. This imperial system unleashed numerous catastrophes, such as wars and genocide in their insatiable appetite for wealth and domination over all life forms. Millions of Africans were conquered and enslaved to provide cheap and replaceable labour force in their new colonies in the Americas. As colonialism and globalisation mutated into the $20^{\text {th }}$ century, other forms of expressions emerged, such as fascism, nationalism, communism, capitalism, as well as scientific and technological advancement. The International Order (Disorder?) created by the political and economically stronger nations has resulted in the weakening of sovereignty of many poorer nation states by transnational economic and financial institutions. This loss of sovereignty by the poorer nations has caused their governments and economic system to become enslaved to serving the external powerful interests that demand from the poor and the environment endless sacrifices. The second volume on Globalisation by Boesak and Hansen offers in-depth reflections on world trade; development and justice; the future of the welfare state; patents on life forms; consumerism; gender traditions; democracy; human rights; militarisation; war and peace; religious and ethical education; food issues; water; ecological issues; human dignity; and theological foundations (2010: v-vi). Such diverse areas of impact by globalisation illustrate why it constitutes a serious challenge to how ecclesial institutions bear witness to fullness of life for humans, and the environment within the Southern African context.

\section{The Rise of Liberal Democracies and the Neoliberal Economic Agenda}

There is much confusion over the understanding of the term liberal democracy. According to Helena Rosenblatt, the confusion and mistake over the terms are due to the mistake of conflating democracy with liberalism (Helena Rosenblatt 
2018). These are not coterminous, nor do they have similar history or agenda. The founders of liberalism were no democrats (Helena Rosenblatt 2018). Western expressions of democracy is experiencing a crisis of confidence. Democracy in the contemporary neo-liberal model exists in a highly delicate liminal state, like a bubble ready to burst at any time, where people no longer have confidence in their leaders and the institutions to deliver the promises of democracy. Neoliberalism's agenda necessitates that powerful and wealthy elites that serve the interest of a free market control the democratic institutions and systems of governance. In the Accra confession of 2004, neo-liberalism is referred to as 'a political-economic philosophy that de-emphasizes [sic] or rejects government or other intervention in the economy; it would allow the market to operate without restraints or protections' (World Alliance of Reformed Churches 2004; The Accra Confession: Covenanting for Justice in the Economy and Earth, Geneva, Switzerland). According to Evans (2005:197), 'liberalism preaches the false universalism of 'free trade' for all, while, in reality, the contemporary neoliberal trading system does not even offer the South a level playing field'. Christi Van der Westhuizen argues that neoliberal capitalism utilises the lexicon of liberty, liberalism and deregulation (Boesak \& Hansen 2009:3), and although aspects of globalisation are unavoidable and inevitable, it is to a great extent, the policy decision made by powerful elites to defend their interest through the ideology of neoliberalism (Boesak \& Hansen 2009:1). The policies, rules and political decisions made by the global institutions that promote neoliberalism and globalisation do not usually benefit the interest of Africa nations, who are considered weak and impoverished. This global model of economic development has resulted in winner and losers. It has produced immense wealth for a minority. According to Athena Peralta, 'for decades, poor and indebted nations in Africa, Asia and Latin America had suffered and continue to suffer the same appalling conditions following Structural Adjustment Programmes imposed by international financial institutions' (Peralta \& Athena 2013). The Market economy within the $21^{\text {st }}$ century is undergoing great change in which global trade is being organised and transformed by the agenda of the Fourth Industrial Revolution $\left(4^{\text {th }} \mathrm{IR}\right)$ at a time when traditional models of democratic governance are being overturned by the rise of populist leaders and government that advocate neo-conservative/ nationalist ideology. Their rules and agenda shapes how the global economic and financial architecture operates in deciding who become winners and losers. The consumers in this Market are deceived into 
believing that they are participating in 'free trade' but it is neither free nor fair because the polices that shape the Market are decided through conflict-ofinterest relationships. Within the context of Southern Africa, the impact on people is made even worse by incompetence among national leaders, inefficiencies and corruption, mixed with externally driven financial capturing of the state through negative impact of globalisation on the economies that have destroyed millions of lives.

\section{The Fourth Industrial Revolution $\left(4^{\text {th }}\right.$ IR) and the Oppression of the Poor}

The agenda of global ecumenical organisations and the ecclesial community within the Sub-Saharan context have a most daunting task in this era of the Fourth Industrial Revolution, and attendant Artificial Intelligence, where the relationship between the economy and ecology has become even more dysfunctional. Imperial life-denying forces of militarism, capitalism, culturalism and technology are to blame. In this $4^{\text {th }} \mathrm{IR}$ era that determines economic advancement through cyber/physical interaction as well as scientific and technological development, systems are designed and utilised to benefit political and economic power of the privileged elite. For the African context, this model is fast-tracking unjust economic development that threatens sustainability of the earth and its resources, along with earth's capacity to renew life. The rapid warming of the earth's climate with consequential rising sea levels, flooding of coastal towns and villages, droughts affecting many farmlands, deforestation, and water pollution are impoverishing the most vulnerable people of Africa.

The underlying premise of the neo-liberal economic order practiced through capitalism is predicated on the philosophy that human beings as free moral agent have the right to control and organise the environment in which they live in ways that meet their needs. However, this anthropocentric hermeneutics with an agenda focused on meeting human needs has created great harm to wider biosphere. The fundamental challenge for religious within the African context that are serious about working with people in local communities for economic justice necessitate a critique of the economic system from which they benefit, and which at once degrades ecosystems.

This overview on the global economy seems to suggest that economic globalisation has served over the modern era to strength the economic systems 
of powerful nations and advance the wealth of the minority wealthy at the expense of the global majority poor, many of who are within the Sub-Saharan context of Africa. This intentionally created system of inequality has produced failed states built on political and economic instability, insecurity and corruption that thrive on social conflict and poverty. Therefore, an inextricable link must be recognised between the unjust system of economic globalisation and the production of poverty. In this contemporary age of deep mistrust for politicians and political, economic and religious institutions, there is great urgency to transform the institutions and their leadership so that they can better serve the best interest for majority of society.

\section{The Southern African Context}

Within the Sub-Saharan context where the Southern African region is located, it is claimed that 40 percent of the region's countries are at high risk of debt (Giles, Chris \& Pillings 2018). These countries are unable to service their debts/loans and the private commercial banks do not normally practice forgiveness of debts and only under onerous terms agree to restructuring of debts. The Southern African region (SADEC) comprised of Angola, Botswana, Comores, Democratic Republic of Congo, Eswatini (former Swaziland), Lesotho, Madagascar, Malawi, Mauritius, Mozambique, Namibia, Seychelles, South Africa, United Republic of Tanzania, Zambia and Zimbabwe. ${ }^{1}$ According to the Southern Africa Economic Outlook for 2018,

Despite the improvement, economic performance remains subdued as the region's economic outlook continues to face major headwinds: high unemployment, weak commodity prices, fiscal strain, increasing debt, and high inflation. Real GDP is estimated to have grown at an average of 1.6 percent in 2017, before increasing to a projected 2.0 percent in 2018 and 2.4 percent in 2019 (SAEO 2018).

The usual response of the global financial regulators such as the World Bank and the International Monetary Fund (IMF) to the financial crisis in developing nations of the Global South is to demand a drastic cut to the national budgets

${ }^{1}$ See https://www.sadc.int/member-states/ for more information (Accessed 10/1/2019). 
that in turn affect spending in the social services sector of the economy. Therefore, those services that affect the wellbeing of the poor within the society, such as healthcare and education, are usually the first to be sacrificed. On the other hand, new taxes are raised, not by taxing the rich and those who can most afford to pay, but by taxing the poor, who are most vulnerable to the negative consequences of increased taxation. The increase of value added tax (VAT) on the basic food items such as bread, maize meal, and rice that the poor depend on for their daily living constitute a repressive tax that can make the poor even poorer (Kaisa Alavuotunki, Kaisa Alavau Mikka \& Jukka Pirttila 2018). The example of Zambia serves as an important example of taxation policies within Sub-Saharan economies that are seeking to expand their tax base to include the informal sector:

The contribution of informal sectors to economic growth is significant in Zambia and other African countries, making taxation of SMEs, which form a significant part of the informal sector, an important issue for tax administrations. The vast number of SMEs and their economic nature (narrow taxable base, undocumented, cashbased business transactions, high mobility and activity in rural areas) in developing countries are the two reasons why tax administrations face difficulties in properly administering this group of taxpayers. This is even more pronounced in African countries where tax administrations encounter various capacity constraints in terms of skills and financial resources (Nhekairo 2014).

With the absence of effective progressive and functioning income tax policies and collection systems, Sub-Saharan governments, many of which are unaccountable to the people, opt for VAT as an expedient approach to increase revenue. In South Africa, for example, the recent VAT increase that increased it from $14 \%$ to $15 \%$ has triggered intense debate among economists (The Conversation 2018). VAT affects the poor disproportionally through the negative impact on price of goods and services, and inflation. The contemporary socio-economic landscape of Sub-Saharan African nations has resulted in a toxic mixture of poverty, extreme, isolated wealth, and ecological degradation. According to Hewitt (2017: 115-131), international market forces exploit Africa's vulnerable economy, while the local factors of corruption and inefficiencies have made many of the economies non-competitive at the global 
market place. In certain African parliaments, members are 'bought' though campaign funding to pass and protect laws that ensure that every aspect of democratic politics, from the choices of voters, to the decisions of politicians, is submitted to the agenda of the market (Hewitt 2017:110).

The imperial weapons of militarism, capitalism, culturalism, and technology serve as strategic forces to enforce the agenda of the empire. The Accra confession statement reminds us that God's work in the world is acted out in the midst of empire, defined as:

The convergence of economic, political, cultural, geographic, and military imperial interests, systems, and networks for the purpose of amassing political power and economic wealth. Empire typically forces and facilitates the flow of wealth and power from vulnerable persons, communities, and countries to the more powerful .... Empire today crosses all boundaries, strips and reconstructs identities, subverts cultures, subordinates nation states, and can marginalize [sic] or co-opt religious communities (North American Covenanting for Justice Working Group 2007: 6).

This all-embracing definition has pushed the understanding of empire beyond the traditional and classical approach that makes it a uniquely western phenomenon because the forces of globalisation has made empire a truly global phenomenon.

CWM further describes empire as follows:

A coming together of economic, cultural, political and military power [...] that constitutes a reality and a spirit of ...domination... an allencompassing global reality serving, protecting and defending the interests of powerful corporations, nations, elites and privileged people, while imperiously excluding even sacrificing humanity and exploiting creation ... (CWM Theology Statement 2010).

In the anti-imperial discourse of Rastafari ideology, this empire is embodied within the biblical concept of 'Babylon', that oppressive system (Shitem) which Bob Marley described as 'vampire' that is 'suckin'" the children day by day' and 'suckin' the blood of the sufferers (Bob Marley, Babylon System Lyrics). Bert Gerdenk argues that there is a direct correlation between the 
uncontrolled market and the development of new military weapons and strategies, and the increasing militarisation of political action. The phenomenal increased in global military spending and the consequential decline in social security spending have helped to create structural violence that further creates impoverishment (Boesak \& Hansen 2010:115-116).

\section{Retrieving Indigenous Knowledge Systems to Enhance Mission in sub-Saharan Africa}

However, if Africans in Sub-Saharan contexts are to experience economic wellbeing, prosperity, and social and economic empowerment, then they need to reclaim their indigenous knowledge systems that possess resources for solutions to their problems, instead of being enslaved to western economic hegemony and cultural effacement (Prah 1998:69). This paper argues that Africans have, by sheer necessity, found a way of living in and with contradiction. Their African indigenous worldview, according to Masondo (Hewitt \& Kaunda 2018:112), values personhood that is relational and lives in community for self-identification embraces an ubuntu world that invites all to participate in community life. Focus is placed on building healthy communities in which the physical and spiritual world work together for the common good of all.

However, with the embrace of western Christian religion that presented faith as a spiritual matter that prepares persons for the afterlife and economics as a 'worldly' matter, the institutional Church became by default an ally of the dominant neo-liberal economic order. These churches have not recognised the importance of how the global economy and its financial architecture impact on local communities and the lives of ordinary people. According to David Coates, 'Often times faith leaders tend to be focused on personal finance and financial literacy in the household, but they have not been drawn into the whole understanding of macroeconomics' (Camacho 2018).

\section{Neoliberalism, Capitalism and Western Christianity}

Polanyi states that it was only during the last two centuries that the market rose above previous market demigods to become its self-proclaimed 'first cause' (Polanyi 2001). This strategic partnership of neoliberalism and capitalism, especially within western Christianity, with some notable economic successes 
that have increased the wealth of some people, has also destroyed the lives of millions of people and the environment through rampant abuse of the earth's resources and climate. Neoliberalism constitutes an indispensable ideological construct for the 'free-Market' requirements of global capitalism. Westbrook argues that:

Modernization [sic], mostly along capitalist lines, became the Universalist creed that glorified the autonomous rights-bearing individual and hailed his rational choice-making capacity as freedom. Economic growth was posited as the end-all of political life and the chief marker of progress worldwide, not to mention the gateway to happiness (Westbrook 2017).

The current global neo-liberal economic paradigm that affects the Southern African context assumes that free market must function without state intervention in order to bring prosperity for all, promote growth and eradicate poverty. However, the high levels of poverty and inequality within Africa suggest that this economic model does not serve the best interest of the people.

According to Harvey Cox, the global marketplace functions as an alternative 'invisible god' that knows and controls how the world ought to do business and its theology focus upon:

Chronicles about the creation of wealth, the seductive temptations of statism, captivity to faceless economic cycles, and, ultimately, salvation through the advent of free markets, with a small dose of ascetic belt tightening along the way (Cox 1999).

Cox further claims that this market mimics the Old Testament deity Yahweh, communicating to the world that it is sovereign and superior to all other economic models of governance and therefore must have total control and be universally accepted, with no opposition, because there is no authentic alternative. Therefore, it can be argued that, it was this uncritical embrace and alliance of western Christianity with neoliberalism over the centuries of the modern era that has replaced faith in the God that Jesu bequeathed to the Church with the ideology of the capitalist's doctrine of 'market as god'. Cox best sums up the conundrum of this unholy relationship between western Christianity and the market in the following words: 
The lexicon of The Wall Street Journal and the business sections of Time and Newsweek turned out to bear a striking resemblance to Genesis, the Epistle to the Romans, and Saint Augustine's City of God. Behind descriptions of market reforms, monetary policy, and the convolutions of the Dow .... Theologians call these myths of origin, legends of the fall, and doctrines of sin and redemption. But here they were again, and in only thin disguise ... (Cox 1999).

In conversation with Cox, the contemporary era has seen traditional mainline Protestant Christianity gone into retreat in Western postmodern societies. They have been dislodged and relegated from the centre of public life by new forms of religious faiths. Their uncritical alliance with neo-liberal economic order that promoted unbridled capitalism meant that they were no longer able to serve the interest of the poor and therefore became irrelevant to their lives. The Church's failure to connect its life and work with the felt needs of poor has led to an exodus from their community to new centres of spirituality to experience life-giving faith. According to Hewitt, (Ecumenical Review 2015: 549):

The vitality recession in some Western brands of Christianity is also accompanied by the impotence of many democratic political systems to facilitate genuine change that can better people's lives, especially of the poor and marginalized [sic]. This failure has influenced the disenchantment of many who are refusing to participate in the democratic process, and some have even turned to violent and destructive forms of protest to vent their anger without taking into account the consequences of their action.

The neo-conservative brand of populist religious expressions has taken their disillusionment with contemporary forms of democratic governance and institutional religions one step further in offering an alternative theological justification for the virtues of capitalism and the neoliberal economic disorder. This brand of western neo-conservative religious faith places controls over human freedom and individual choice. This perspective on human freedom thrives on blame, instead of exercising agency, and has become the new religious defender of neo-liberal economics that has struck global strategic alliance with despotic and nationalistic anti-democratic forms of governments. This schizophrenic expression of religious faith embraces neoliberal economy 
that promotes rampant capitalism, yet on the other hand, it identifies neoliberalism as an enemy of the nation state, that must be defeated. As a result, it promotes an anti-liberal, conservative governance that embraces life-denying attributes that restricts the human rights of people based on social, political, religious, sexual, gender and racial identity.

This populist religious discourse has further rooted itself in the new info-tech and bio-tech world order that is driven by the Fourth industrial Revolution $\left(4^{\text {th }} \mathrm{IR}\right)$. In this new environment, human rights, according to Jung Mo Sung, are under grave threat from anti-humanism/post-humanism, neoliberalism and trans-humanism era, all of which are attacking notions of human rights, social justice, and justice in the marketplace (Sung 2018:124130).

The WCC statement on, Just Finance and an Economy of Life, appealed for an ethical, just and democratic international financial regime that is,

grounded on a framework of common values of honesty, social justice, human dignity, mutual accountability and ecological sustainability,

and that,

account[s] for social and ecological risks in financial and economic calculation; reconnect[s] finance to the real economy; and set[s] clear limits to, as well as penalise[s], excessive and irresponsible actions based on greed (WCC Statement on Just Finance 2009: 1).

The paradox is that life-threatening issues of poverty, hunger; Aids, tuberculosis (TB), malaria; environment, soil fertility, pollution, water; industry, business, economy, unemployment impact on the daily lives of most Africans. However, this core economic dimension of their lives exist in a liminal space, living in contradiction and disconnected from the understanding and praxis of their faith. According to Morawski (1996:56),

Liminality points to the paradoxical and potentially transformative valences of being in a marginal time/space, but it does not reveal the specific kinds of work activities that transpire within nor does it tell how liminal agents are transformed and thus move out of liminality 
and into newer social relations and practices.

Liminality participants are caught in an 'already/not yet' space of existence as they seek for meaning and purpose in their lives. According to Van Gennep (1960:40), the liminal process of detachment is highly ambiguous. This disconnectivity between their economic life and their life of faith creates a schizophrenic identity crisis characterised by confused belief systems. In view of the many Christians within the African ecclesial context, their pedagogical faith formation generally divorces their faith from matters of economic justice. The partnership of European colonialism and imperialism with the expansion of the Christian religion bequeathed a Euro-centric religio-cultural dualist worldview, in which two fundamental forces/realities that embody good and evil are in permanent contestation and struggle for the power to control humanity and the wider world. In a comment on racism and Eurocentric modernity, Vellem (2018: 37) argues that:

The ghost of colonial conquest, a Europeanized [sic] object, legitimized [sic] by a Christianizing [sic] spirit of the Europeanization [sic] of the world, comes back to haunt us and will continue to do so if its core remains untouched.

\section{The Changing Landscape of Christianity within Africa}

The World Council of Churches document 'Together Toward Life' (TTL) (Keum, 2013, 13) states that the myth of the neo-liberal market ideology constitutes 'a threat not only to economic life but also to the spiritual life of people, and not only to humanity but also to the whole creation'. The ecclesiastical community's responsibility is to be an advocate on behalf of those who live on the margins and are denied fullness of life by the global market that serves the interest of the economic powerful. It is against this background that one ought to interrogate the Church's response to the challenge of economic justice within the Southern African context. According to the Pew Report:

Christianity has grown enormously in Sub-Saharan Africa and the Asia/Pacific region, where there were relatively few Christians at the beginning of the 20th century. The share of the population that is 
Christian in Sub-Saharan Africa climbed from 9\% in 1910 to $63 \%$ in 2010, while in the Asia/Pacific region it rose from $3 \%$ to 7 percent $^{2}$.

The Pentecostalisation of Christianity and the rise of other charismatic movements within Africa have embraced pneumatological paradigm of communicating the Christian faith that intentionally seeks to address what is prioritised as health, wealth, and prosperity of the people. Their enterprising pastoral leaders embraced this new Market ideology with a gospel message that celebrates and blesses the economic practices that grow their prosperity gospel and promise health, wealth, and success. According to the ecumenical evangelical network of the Lausanne Theology Working Group (2010: n.p.), prosperity gospel is defined as,

The teaching that believers have a right to the blessings of health and wealth and that they can obtain these blessings through positive confessions of faith and the 'sowing of seeds' through the faithful payments of tithes and offerings.

This brand of Christianity has found welcoming accommodation in many African societies, with a culture and worldview that integrate the physical life with the spiritual life, and where the people are therefore open to miraculous intervention in their lives by means of which to deliver the blessings of health and wealth. Pastors claim to be filled with the spirit of God and are empowered to take back from the Devil, the Evil One, that which he has stolen from the people of God. However, in the practical expression of this prosperity gospel, money has become the magnet for acquiring quick wealth. These enterprising religious practitioners use 'miraculous healing' as a commodity that is sold to those who can 'give/pay' to access the benefits. Those with greater financial resources can access and receive priority rewards of healing and health benefits. The contemporary public debates in many of the Southern Africa

${ }^{2}$ The study finds that more than 1.3 billion Christians live in the global South (61\%), compared with about 860 million in the global North (39\%) in 2010, see 'Global Christianity: A Report on the Size and Distribution of the World's Christian Population,' Pew Research Centre, 19 December 2011, at: http://pewforum.org/Christian/Global-Christianity-worlds-christianpopulation.aspx (Accessed 30/11/2018) 
regional contexts focus on negative consequences of unaccountable ecclesiastical leaders who are caught in moral and ethical conundrum linked to sexual abuse and financial greed. Within the South African context in particular, both print and electronic media have regularly featured cases where such practitioners prey upon venerable people seeking quick solutions.

Both mainline churches and other religious groups linked to the neoconservative/charismatic and populist traditions use different approaches to engage with the neo-liberal economic order and their financial institutions. However, these ecclesial traditions see unable to exercise critical distance from the infectious and addictive lure of the love of money, and are captured by the same economic ideology that has corrupted and discredited their public witness.

\section{Ecumenical Praxis for Economic Transformation}

The use of ecumenical praxis for economic transformation constitutes an unused resource that is available to ecclesial communities within local communities. The economic transformation that is urgently needed to address injustice in many local communities requires participation from religious communities that are able to employ life-affirming theological reflections to deepen faith praxis within their contexts. Authentic life-giving faith must enter into solidarity with people who live on the margins of society and whose 'cultures and systems which generate and sustain massive poverty, discrimination, and dehumanization [sic], and which exploit or destroy people and the earth' (Keum 2013: 15). This model of theological reflection draws upon the ordinary peoples' resources of faith, scripture, tradition, and experience to resist and overcome systemic threats to life. In order to break free from the magnetic lure of neoliberalism and neo-conservative socio-economic, political and theological systems of oppression, a process of radical re-reading of the bible from its state of capture by colonial and imperial institutional forces and Eurocentric missionary cultural bias that protected the interest of the powerful is imperative. The ecclesial community has a prophetic role to confront political and economic decisionmakers so as to promote life in dignity for all creation.

\section{Oikos: Economy, Ecology and the Earth}

In order for local ecclesial communities to be faithful disciples and followers of Jesus, they too must arrive at an understanding of nature and purpose of the 
Church, moving beyond agreeing to statements of faith and order to missiological praxis that embraces economic justice. The economy is predicated on sustaining life. A John 10:10 states, 'God is the God of life'. The economy cannot be separated from the very mission of God in Christ (Missio Dei). Therefore, the historical Jesus of Nazareth, who is professed by Christians to be the Christ of their faith, stands as God's affirmation to the world. This affirmation invites the Church that constitutes all of those who are disciples of Jesus to participate in God's continuing work of salvation (fullness of life) for all that celebrates justice and peace. The World Council of Church and the Commission on Mission and Evangelism (WCC/ CWME ) document, 'Together Towards Life' affirms that 'Life' must be experienced as life in all its fullness, that is, as abundant life (Keum 2013:4-7), and it includes biological, human, social, and eternal, as well as economic well-being and ecological health. Furthermore, the Holy Spirit is 'the Breath of Life' (Keum 2013:7). Therefore, a denial of life is a rejection of the God of life, and the Church that is the gathered community of the followers of Jesus is commissioned to celebrate life, and to resist and transform all life-denying forces in the power of the Holy Spirit. This missional understanding of the fullness of life is also referred to as 'The Economy of Life', because it places the whole oikoumene - that is, the household of God - at the centre of the Church's mission and cares for the whole inhabited Earth, land and sea (World Council of Churches - World Communion of Reformed Churches - Council for World Mission - the Lutheran World Federation Statement on the occasion of the $3^{\text {rd }}$ United Nations (UN) Financing for Development Forum New York, 2326 April 2018).

The nature of the Church's life and work in local communities has major implications for how it respond to threats to the future of the planet. The concepts of economy and ecology are both rooted in the Greek word, oikos that refers to the global home or household. Economy also refers to the Greek concept of nomos, or rules that govern the home or household. Ecology is integrally rooted in the concepts of oikos and logos pertinent to how the elements in the home or household work together for the common good. Human beings and other forms of life that inhabit this planet earth are all interrelated. The word 'economy' (oikonomia) refers to the management of a household. Economic justice is a concept that describes equitable sharing of resources and economic power as essential conditions for human development and ecological sustainability. Economic justice refers to how economic life is 
organised in terms of production, distribution, and consumption of material goods and services. Therefore, economy and ecology must work together for the common good of all.

\section{Making Economic Justice a Matter of Confession Faith}

At the Sao Paulo 2012 meeting of the WCC, WCRC, LWF and CWM, a declaration was issued that called for, 'urgent transformative liberation from unjust financial and economic structures are a direct response, then, to a call from God to join in God's freeing, healing, creating, sustaining activity in the world' (World Council of Churches - World Communion of Reformed Churches - Council for World Mission - the Lutheran World Federation Statement on the occasion of the $3^{\text {rd }}$ United Nations (UN) Financing for Development Forum New York, 23 - 26 April 2018). They recognised that radical changes are needed at the global macro-level to transform the state of economic development of nations, because the forces that are in the world transcends national borders and interest and functions to serve the interest of a few very powerful interest groups. It is for this reason that ecumenical organisations recognise the urgency of networking in order to lobby and challenge global economic and financial structures and to recognise the urgency for changes that can transform the lives of millions of people in the global south.

At another ecumenical gathering of African women in Tanzania to discuss issues on poverty, wealth, and ecology, participants characterised the hybrid neo-liberal economic model that engages in strangle-hold of the nations and denies meaningful life to many of its peoples as one that has:

... damaged Africa's ecological fabric. The privatisation, commodification and commercialisation of land, water and seeds through largescale mining projects, the construction of mega-dams and neoliberal trade policies have fragmented and displaced entire communities in Africa, blocking them off from their sources of sustenance. African people are forced to migrate as a survival mechanism; and many African women have fallen victim to trafficking (African Women's Statement on Poverty, Wealth and Ecology 2007).

Within the Sub-Saharan context, the important issues of economy and faith must be rooted in the value of justice and peace. African women employed a 
contextual theological framework of liberation as an appropriate discourse to interrogate the relationship between the economy and faith. They argue that the economy that shapes how people live must be the subject of faith, because the Christian concept of justice is foundational to expression of faith. However, the quest for economic justice necessitates the mobilisation of joint ecumenical action at global and national levels, because local faith communities on their own will not be able to engage with the powerful forces unleashed by neoliberal economic disorder. Transformative ecumenical praxis equips the ecclesial community to resist all life-destroying values and systems in the political, social economic, and religious environment. Therefore, economics and economic justice must inevitably be treated as matters of faith, because they are important components in God's fullness of life for all creation (Alternative Globalization Addressing Peoples and Earth (AGAPE) 2005:13).

It is significant that when the global ecumenical organisations of WCC, LWF, WCRC and CWM planned their ecumenical focus on economic justice, that it was the African continent, and in particular, the context of Ghana, that was chosen. This West African nation poignantly represents the wider African context, experiencing upheavals from the negative impact of global economic dis-order on the African environment, while affecting climate change and the wellbeing of humanity, plants and animals. Their definitive stand on the centrality of economic justice in the understanding and praxis of faith was articulated in the 2004 ecumenical conference document, 'The Accra Confession' that affirmed that justice as matter of faith. It stated that:

... matters of economic and environmental justice are not only social, political, and moral issues: they are integral to faith in Jesus Christ and affect the integrity of the Church. Being faithful to God's covenant requires that individual Christians and the churches take a stand (World Alliance of Reformed Churches 2004: 10).

This ecumenical process that argued for Covenanting for Justice in the Economy and the Earth and the need for an alternative to globalisation to address the needs of peoples and the earth, was highly unpopular among many churches in the Global North. They viewed the process as a 'left wing' attack on their economic and financial systems that ensured them their wealth, and they were in no haste to dismantle or destroy that which made them an economically privileged people. It was the financial crisis of 2008 that resulted 
in systemic failures in financial regulation and supervision by corporate governance and risk management of the 'free market' (The Economist 2013). Whereas some government sought to bail out the big banks that were considered 'too big to fail', many ordinary investors and nations paid dearly, and suffered severe loss. This global economic failure convinced some churches in the North to embrace the quest for economic justice as a missional priority. The effects of this financial failure are still being felt within the African context, and this has made the focus on the theme of economic justice as a confession of faith even more important in this contemporary era, due to the catastrophic fallout from economic globalisation on the wellbeing of people.

\section{Economic Injustice and the Mission of Jesus}

Local churches within the African context must therefore rediscover the politics of Jesus within the context of the Roman imperial world. His witness embraced those who were most marginalised in society. Therefore, the ecclesial witness involves struggle and resistance in the quest for justice and inclusivity, healing and wholeness (Keum 2013: 15), and it includes the nonhuman dimension of creation. Since millions of Africans live on the margins of their society, the mission of their local church is to engage in radical diakonia (servant ministry as modelled by Jesus). This praxis 'invites political engagement that involves taking strategic action to speak against injustice and fight for human dignity' (Hewitt 2017: 110).

If the Church in the Southern African context is to incarnate the diakonial ministry of Jesus overcome economic injustice, then it must intentionally opt for solidarity with the people who are 'the sinned against' and are demonised by those at the centre of political economic and religious power. Failure to model the ministry of Jesus may discredit the Church's authenticity, because through silence it risks becoming a legitimiser of person and systems of power and wealth that are built on greed, and designed to benefit the privileged few at the expense of the many. Jesus made economic justice issues central to the integrity and praxis of faith, and allowed no room for neutrality. Although Jesus was not a member of a political party, his message was revolutionary, because it advocated for individual and systemic comprehensive changes within his imperial and colonised society. His messages of liberation consistently identified and analysed all unjust systems of power, and demanded real change in the distribution of authority and power, goods and resources, 
such that the people that lived on the margins might experience fullness of life (Luke 4:18ff). Throughout his ministry, Jesus offered a comprehensive approach to peoples' suffering by addressing not only the physical pain with which they were burdened, but also the systemic causes of their suffering. His political consciousness was shaped within an imperial, colonised context in which ordinary Jewish people were oppressed (Hendriks 2006). Jesus cites the political, religious and economic oppression of the Jews as the focus of his own ministry (Isaiah 61; Luke 4:18ff).

The quest for justice was therefore central to Jesus's ministry: 'blessed are those who hunger and thirst for justice' (Matt 5:6), 'Seek first the Kingdom of God and his justice' (Matt 6:33). Jesus was conversant with the Hebrew Scriptures and familiar with admonitions regarding justice (mishpat) and righteousness (sadiqah) that advocated for the establishment or restoration of fair, equitable and harmonious relationship that leads to fulfil responsibilities of relationship: '... do justice, and to love kindness, and to walk humbly with your God?' (Micah 6:8). Justice and righteousness are thus based on social relationship.

Economic transformation is constructed on the understanding that justice is formative and foundational to the ethics and morality in relationships modelled on the worldview and social consciousness upon which Jesus carried out his ministry. The colonial rule of Roman imperial occupation, along with their local surrogates ensured that the local economy served the interest of the ruling class, and had far-reaching psycho-emotional consequences on the Empire's inhabitants. His alternative way of resisting economic hegemony of empire resulted in his critique of the Religious leaders, who compromised and succumbed to Roman colonial rule to protect their power base. They became spiritually impotent by failing to speak truth to power that was oppressing the poor through high taxes and indebtedness. Both political and religious institutions failed to treat the basic needs of the people as sacred. Therefore, the ministry of Jesus was centred upon empowering the dispossessed poor, while exposing and delegitimising their invincibility and deceptive control of political and religious system that thrived off their poverty.

\section{Conclusion}

Transformative ecumenical praxis for economic justice invites churches to journey from privatised faith understanding to public engagement with the 
oppressed. If the Church in the Southern African context is to be a faithful follower of Jesus and a servant of the poor, then its model of engagement necessitates transformative ecumenical praxis for economic justice that moves beyond inner-ecclesial institutional priorities. Transformative ecumenical praxis in local communities focuses on meeting the ordinary felt needs of the people. This cannot function as a private arrangement by individual churches competing against one another, because the threat to the lives of the poor are both deep and systemic. The ecclesial understanding of ecumenical engagement must therefore rise above the false life restricting barriers of denominationalism that is widespread within the African context. It requires an approach that emphasises oneness through diversity, which includes, accepts and works with the other. Transformative ecumenical relationships are, therefore, covenantal, and rooted in a commitment to justice. Justice in the economy and Market is based on principles of social and climate justice; serves the real economy that benefit the poor; accounts for social and environmental tasks; and sets clear limits to greed. With the presence of injustice, there must not be room for neutrality. The followers of Jesus are expected to take sides with justice, and act against the systems that stand in the way of justice. The global economy must be subjected to the life-affirming values of transformative justice for the common good of all including other life forms. In order to resist the life-denying works of empire, the Church's apostolic mandate is to bear authentic witness to the ongoing life-giving example of Jesu for all creation and this necessitate inseparability of justice with ecumenical misengagement.

\section{References}

Adam, K. 2018. Neoliberalism's Demons on the Political Theology of Late Capital. California: Stanford University Press.

African Women's Statement on Poverty, Wealth and Ecology 2007. World Council of Churches, Geneva.

https://www.oikoumene.org/en/resources/documents/wccprogrammes/public-witness-addressing-power-affirming-peace/povertywealth-and-ecology/neoliberal-paradigm/african-womens-statement-onpoverty-wealth-and-ecology

Alavuotunki, K., A. Mikka \& J. Pirttila 2018. The Effects of the Value-Added 
Tax on Revenue and Inequality. The Journal of Development Studies. https://www.tandfonline.com/doi/full/10.1080/00220388.2017.1400015 Alternative Globalization Addressing Peoples and Earth (AGAPE) 2005. A Background Document. Geneva: WCC Publications.

Boesak, A. \& L. Hansen eds. 2009. Globalisation (The Politics of Empire, Justice and the Life of Faith). Stellenbosch: Sun Press.

Boesak, A. \& L. Hansen (eds.) 2010. Globalisation 11 (Global Crisis, Global Challenge, Global Faith). Stellenbosch: Sun Press.

CWM Theology Statement, 2010. Mission in the Context of Empire. https://onlinelibrary.wiley.com/doi/abs/10.1111/j.1758-

6631.2011.00061_2.x

Camacho, J.D. 2018. Can we afford Economic Justice in the United States?

Sojourners. https://sojo.net/articles/can-we-afford-economic-justiceunited-states

Cox, H. 1999. 'The Market as God': Living in the New Dispensation. The Atlantic. $\quad$ https://www.theatlantic.com/magazine/archive/1999/03/themarket-as-god/306397/

(Accessed on 30 November 2018.).

Giles, C., D. Pillings 2018. African Nations Slipping into New Debt Crisis. https://www.ft.com/content/baf01b06-4329-11e8-803a-295c97e6fd0b

Hendriks, O. 2006. The Politics of Jesus. Doubleday, Random House.

Hewitt, R.R. 2015. The Changing Landscape of Christianity and the Challenging Context of Secularism. Ecumenical Review 67,4. https://doi.org/10.1111/erev.12188

Hewitt, R.R. 2017. Ecclesial Leadership and Social Responsibility within the African Context of Economic Injustice. Alternation Special Edition 19: 115 - 131. https://doi.org/10.29086/2519-5476/2017/sp19a5

Hewitt, R.R. 2017. Reformed Identity and Mission from the Margins. Stellenbosch Theological Journal 3,2: 99 - 122.

http://dx.doi.org/10.17570/stj.2017.v3n2.a04

Hewitt, R.R. \& J.C. Kaunda 2018. Who is an African? Maryland: Lexington Books/ Fortress Academic.

Keum, J. (ed.) 2013 Together towards Life: Mission and Evangelism in Changing Landscapes. Geneva: WCC Publications.

Marley, Bob 2020. 'Babylon System Lyrics.' Lyrics.com. STANDS4 LLC, 2020. Web. 3 Aug. 2020.

https://www.lyrics.com/lyric/3219450/Bob+Marley. 
Morawski, J. 1994. Practicing Feminisms, Reconstructing Psychology: Notes in a Liminal Science. Michigan: University of Michigan. https://doi.org/10.3998/mpub.10112

Nhekairo, W.M. 2014. 'The Taxation System in Zambia': The Final Report, Jesuit Centre for Theological Reflection, https://www.taxjustice-andpoverty.org/fileadmin/Dateien/Taxjustice_and_Poverty/Zambia/JCTR/J CTR_2014_taxstudy.pdf

Peralta, A. 2013. Overcoming Systemic Greed - Do We Need New Global Economic Ethics?

https://altervoicedotorg.wordpress.com/2013/09/29/overcoming-

systemic-greed-do-we-need-new-global-economic-ethics-guest-post-byathena-peralta/

Polanyi, K. 2001. The Great Transformation. Massachusetts: Beacon Press. http://inctpped.ie.ufrj.br/spiderweb/pdf_4/Great_Transformation.pdf

(Accessed November 18, 2018)

Prah, K.K. 1998. Beyond the Colour Line: Pan African Disputations: Select Sketches, Letters, Papers, and Reviews. Trenton, NJ: Africa World Press. Rosenblatt, H. 2018. 'Liberal Democracy is in a crisis. But ... do we know what it is?' The Guardian Newspaper.

https://www.theguardian.com/

(Accessed 10/1/2019).

Ross, R.K., J. Keum, K. Avtzi \& R.R. Hewitt (eds.) 2016. Ecumenical Missiology, Changing Landscapes and New Conception of Mission 35. Oxford, UK \& Geneva: Regnum Books \& WCC.

Southern Africa Economic Outlook 2018. African Development Bank Group. https://www.afdb.org/fileadmin/uploads/afdb/Documents/Publications/2

018AEO/African_Economic_Outlook_2018_Southern-Africa.pdf (Accessed 10/1/2019)

Sung, M.J. 2018. Religion, Human Rights and Neoliberalism in a PostHumanist Era. The Ecumenical Review 70,1,March, Oxford: John Wiley \& Sons Ltd. https://doi.org/10.1111/erev.12334

The Conversation 2018. Connecting the Dots between the Hike in South Africa's VAT and Inflation. http://theconversation.com/connecting-thedots-between-the-hike-in-south-africas-vat-and-inflation-93668

The Lausanne Theology Working Group 2010. Statement on the Prosperity Gospel. https://www.lausanne.org/content/a-statement-onthe-prosperitygospel 
The WCRC-WCC-CWM Sao Paolo Statement on International Financial Transformation for an Economy of Life. Available at: http://www.oikoumene.org/en/resources/documents/wccprogrammes/public-witness-addressing-power-affirming-peace/povertywealth-and-ecology/finance-speculation-debt/sao-paulo-statementinternational-financial-transformation-for-the-economy-of-life.html

The Economist Magazine. https://www.economist.com/schoolsbrief/2013/09/07/crash-course (Accessed 5/12/18)

Westbrook, R. 2017. The Resentment that Capitalist Modernity Leaves in the Wake. The Christian Century.

https://www.christiancentury.org/review/books/resentment-capitalistmodernity-leaves-its-wake

World Alliance of Reformed Churches, 2004. The Accra Confession: Covenanting for Justice in the Economy and Earth. Geneva, Switzerland: WARC.

World Alliance of Reformed Churches, and World Council of Churches 2007. North American Covenanting for Justice Working Group 2007. Produced by RCA Communication and Production Services.

Roderick Hewitt (PhD)

Systematic Theology

School of Religion Philosophy and Classics University of Kwa Zulu Natal South Africa, and Visiting Fellow New College University of Edinburgh hewitt@ukzn.ac.za 